\title{
Author Correction: The pattern-recognition receptor CORE of Solanaceae detects bacterial cold-shock protein
}

Lei Wang, Markus Albert, Elias Einig, Ursula Fürst, Damaris Krust and Georg Felix

Correction to: Nature Plants 2, 16185 (2017); published online 28 November 2016.

In the version of this Article originally published, Fig. $6 \mathrm{~b}$, which is composed of individual pictures of six plants, inadvertently and erroneously displayed the same image of one Col- 0 wt plant twice. This has been corrected so that Fig. $6 \mathrm{~b}$ now shows two different representative plants for the Col-0 wt control.

Published online: 23 October 2017

https://doi.org/10.1038/s41477-017-0044-2 